\title{
Artigo \\ Turistas estrangeiros e mulheres locais: \\ "mercado do sexo" e romance nas noites \\ da Praia de Iracema em Fortaleza
}

Jania Perla Diógenes de Aquino ${ }^{1}$

Universidade Federal do Ceará

RESUMO: $O$ artigo aborda relações entre turistas estrangeiros e mulheres nativas na Praia de Iracema, em Fortaleza. São apresentadas visões de moradores da orla marítima e bairros vizinhos, cuja percepção dos "encontros" entre "gringos" e jovens locais são estritamente negativas. Por um lado, as mulheres são consideradas "vítimas" dos interesses sexuais dos estrangeiros, por outro são tomadas como "culpadas" por Fortaleza ter se tornado internacionalmente conhecida como polo de prostituição. $O$ texto também analisa narrativas e percepções de garotas de programas atuantes nas noites da Praia de Iracema, que ressaltam experiências positivas proporcionadas por "gringos", tais como consumo de bebidas e refeições em restaurantes sofisticados, presentes, viagens ao exterior e até mesmo namoros e casamentos. Além de ressaltar a indefinição entre negócio e afeto nos intercâmbios sexuais e afetivos entre garotas de programas e "gringos", o artigo argumenta que tais relações interferem nas assimetrias e desigualdades sociais locais.

PALAVRAS-CHAVE: Gringos e nativas, prostituição, turismo sexual em Fortaleza, Praia de Iracema, mercado do sexo transnacional. 


\section{A pesquisadora, o cenário e os personagens da pesquisa}

A Praia de Iracema ou P.I., abreviação recorrente entre seus moradores e frequentadores, é um bairro da orla marítima de Fortaleza, a capital do estado do Ceará, que se tornou mundialmente conhecida, nos anos 2000, como um polo internacional de prostituição. Desde então, bares e boates localizados na parte leste da Praia de Iracema constituem os principais "pontos de encontro" entre homens estrangeiros e garotas de programa na cidade. O "mercado do sexo" ali operante promove intensa movimentação na vida noturna do bairro.

No segundo semestre de 2010, devido a minha participação no INCT $^{3}$ Violência, Democracia e Segurança Cidadã, coordenado pelo Núcleo de Estudos da Violência da UsP, iniciei um trabalho de campo etnográfico na Praia de Iracema. Minha pesquisa focalizava pontos de contatos e intersecções entre atividades legais e ilegais no cotidiano noturno do bairro. Inicialmente minha atenção não foi direcionada especificamente à prostituição. Meu objetivo era identificar situações e contextos em que atividades legais e regulares mantinham estreita relação com práticas ilegais. No desenvolvimento da pesquisa, etnografei diferentes situações em que domínios do lícito e do ilícito se confundiam. Menciono alguns exemplos: presenciei garçons e proprietários de bares atuarem como traficantes de drogas; pude observar frentistas e mototaxistas aliciando adolescentes na atividade prostitutiva; em uma longa narrativa, um barman me detalhou os passos que segue, junto com uma amiga, garota de programa, para aplicar o conhecido golpe "boa noite cinderela" em turistas estrangeiros - a dupla introduz cápsulas de rupinol na bebida das vítimas, que adormecem rapidamente, deixando livre o acesso para dinheiro, cartões de crédito, cheques e objetos pessoais como relógios e cordões de ouro.

Entre setembro de 2010 e dezembro de 2013 realizei contínuas incursões ao cotidiano noturno da Praia de Iracema. Frequentei bares, restaurantes e boates, conversei informalmente e cultivei proximidades com diferentes personagens que circulam nas noites do bairro, e somente depois de dois meses de observação participante realizei as primeiras entrevistas utilizando o gravador. A rápida aproximação com diversas pessoas que se tornaram meus interlocutores na pesquisa foi possibilitada por um feliz reencontro. $\mathrm{Na}$ segunda semana de trabalho de campo, reconheci Luciana em uma boate. Tratava-se de uma simpática jovem que conheci em um vilarejo do litoral cearense. Luciana era recepcionista do hotel onde eu me hospedei, devido a sua atenção e solicitude nos tornamos amigas e confidentes. Fazia um ano que eu não tinha notícias dela e fiquei 
surpresa ao vê-la na P.I. Na ocasião, minha amiga acompanhava dois finlandeses, hóspedes do hotel localizado na orla de Fortaleza, onde ela passara a trabalhar desde o início de 2010. Luciana se mostrou feliz ao me rever e contou que ganhava gordas gorjetas de estrangeiros na cidade, apenas para lhes "assessorar" nas noites na Praia de Iracema, indicava-lhes bares e boates, oferecia-se para acompanhá-los e opinava sobre mulheres que lhes despertavam interesse. Quando contei que estava pesquisando o cotidiano noturno da P.I., Luciana se prontificou a me ajudar. Nas semanas seguintes, ela me apresentou a dezenas de personagens que transitavam nas noites do bairro: recepcionistas e seguranças de hotéis e pousadas, garçons e proprietários de restaurantes e bares, taxistas e mototaxistas, frentistas, vendedores ambulantes e traficantes. Fui mapeando uma complexa rede de relações envolvendo estas pessoas que, em suas atividades profissionais e trocas de favores cotidianas, trafegam entre o legal e o ilegal (Aquino, 2015).

A proximidade com diversos personagens atuantes na Praia de Iracema despertou meu interesse analítico para os "encontros" que ali se desenvolvem entre garotas de programa e homens estrangeiros. Pareciam-me fascinante as expectativas de vínculos afetivos e continuidade na relação por uma parte significativa das mulheres. Ao observar casais que se formavam em poucas semanas e acessar narrativas a respeito de namoros e casamentos iniciados no bairro, quis compreender a indefinição entre afetividade e negócio que permeava tais "encontros". No desenvolvimento do trabalho de campo, fui privilegiando observações e narrativas sobre estas relações, desenvolvi entrevistas em profundidade com doze garotas de programa atuantes na P.I. e com dez mulheres, atualmente casadas com homens estrangeiros, que conheceram seus companheiros quando se prostituíam no bairro - entre estas, cinco residem na Europa, duas nos Estados Unidos e três em Fortaleza.

Concomitante ao interesse nas relações entre garotas de programa e homens estrangeiros, passei a realizar um experimento analítico junto a moradores da Praia de Iracema e de dois bairros vizinhos a este: Meireles e Aldeota. Procurava compreender visões e posicionamentos destas pessoas a respeito do cotidiano noturno na P.I., suas dinâmicas e personagens. Privilegiei moradores dos três bairros mencionados, não por corresponderem a redutos da classe média e alta de Fortaleza, mas pela proximidade geográfica de ambos com os locais onde se desenvolve o "mercado do sexo" na Praia de Iracema. Considerando que sou moradora do Meireles e transito cotidianamente pela Aldeota e a Praia de Iracema, tratei de ficar atenta a conversas, relatos e comentários, cujos temas estivessem relacionados ao cotidiano noturno da P.I. Em ambientes os mais diversos, 
como academia de ginástica, restaurantes, lojas, praças, dentre outros, ao presenciar tal menção, eu procurava me aproximar e participar da conversa, informava sobre a pesquisa que estava desenvolvendo e tentava marcar entrevistas. Não foi difícil conseguir colaboradores para a pesquisa. No intervalo de um ano realizei vinte e cinco entrevistas, todas sem uma estrutura pré-estabelecida. A partir dos temas "noites da Praia de Iracema", "turismo sexual" e "prostituição", os entrevistados falaram livremente, apresentaram suas narrativas e argumentos.

$\mathrm{Na}$ condição de fortalezense, tenho acompanhado a expansão do turismo sexual e da prostituição na cidade há pelo menos duas décadas. Tais fenômenos desencadearam mudanças impactantes nos usos e significados atribuídos à Praia de Iracema. Este bairro que tinha suas noites frequentadas por elites intelectuais e econômicas da cidade, durante o decênio de 1990 passou a se caracterizar pela incidência da prostituição direcionada a turistas. Há longa data, portanto, ouço relatos e posicionamentos de outros fortalezenses, sobretudo de moradores da orla e bairros vizinhos, demonstrando tristeza e indignação com que o costumam denominar "invasão das putas e gringos". Sendo assim, procurei, por meio de conversas informais e entrevistas realizadas, colocar em relevo e analisar estas falas, mapear e compreender visões e posicionamentos.

A condição nativa do(a) antropólogo(a), que tem ensejado intensos debates na Antropologia nas últimas décadas (Sahlins, 2001; Cardoso de Oliveira, 1993), em larga medida, caracteriza minha experiência com a temática abordada neste texto, em que lido com personagens e fenômenos diretamente relacionados à cidade onde resido. Nesta investida heurística, ao buscar desenvolver diálogo com dois universos sociais distintos, precisei me equilibrar entre posturas aparentemente oponentes, tais como distanciamento, identificação e estranhamento. No trabalho de campo realizado junto a garotas de programa e ex-garotas de programa empreendi tentativas de aproximação diferentes das que utilizei nas entrevistas junto a moradores dos bairros Praia de Iracema, Meireles e Aldeota.

Diante das garotas de programa e ex-garotas de programa com quem desenvolvi diálogo na P.I. procurei não parecer uma “estranha no ninho" e inspirar alguma confiança nas minhas interlocutoras. Ter sido vista em companhia de variados personagens que transitam nas noites do bairro, facilitou minha aproximação com estas mulheres. Mesmo assim, havia uma larga distância social entre nós, menos devida a diferenças econômicas, que a estigmas atrelados à atividade prostitutiva. Em diversas ocasiões a alteridade entre observadora e observadas se fez sentir pela curiosidade que manifestavam em relação a 
sanções morais que eu poderia sofrer por frequentar bares e boates da P.I.: "Mulher, o quê que o povo diz de você vir pra cá?"; "Sua família sabe que você vem aqui?”; "E se alguém te vir, vão achar que entrou pro babado?"; "Você não liga se pensarem que você faz programa?". Para algumas interlocutoras, marcar presença nas noites do bairro comprometeria minha reputação de "mulher direita", levando-me a "cair na boca povo".

De minha parte, a possibilidade de encontrar parentes e conhecidos enquanto desenvolvia aquele trabalho de campo nunca foi um problema. Tendo pesquisado por nove anos o universo dos assaltos contra instituições financeiras (Aquino, 2010), recebi críticas e admoestações contínuas de familiares e amigos que tentaram me convencer a mudar a temática da pesquisa ou a desenvolvê-la com base em dados secundários. Ter insistido em incursões etnográficas junto aos chamados "assaltantes de bancos" me emancipou não só para realizar aquele trabalho, mas também para futuras pesquisas. Ao ganhar o apelido jocoso de "cientista de tudo o que não presta", sinto-me livre para etnografar outras modalidades de "outsiders morais" sem causar surpresa ou comoção entre as pessoas de quem sou próxima.

Se as noites da P.I. e suas garotas de programa por vezes me fazia sentir uma leiga, sem domínio do jogo social ali operante, as conversas e entrevistas realizadas com moradores dos bairros Praia de Iracema, Meireles e Aldeota envolviam um universo no qual me considero "iniciada", creio compreender narrativas e argumentos apresentados. Em alguma medida, entendo como opera o raciocínio dos entrevistados ao elaborarem classificações e visões. Houve uma certa identificação com estas pessoas por morarmos na mesma região da cidade, transitarmos nos mesmos lugares, em alguns casos chegamos a identificar amigos e parentes em comum. Nossa proximidade, no entanto, não ia muito longe. Devido à experiência de inserção no cotidiano noturno da Praia de Iracema e a minha formação intelectual e moral pautadas no respeito à alteridade, não podia concordar com suas afirmações sobre os temas e personagens em discussão. Experimentei situações similares àquelas mencionadas por Vincent Crapanzano (1986) em seu trabalho de campo na África do Sul, junto a interlocutores brancos e racistas. O antropólogo assinala sua antipatia em relação às atitudes e ideias das pessoas com quem precisava desenvolver diálogo. Assim como Crapanzano, evitei externar minhas discordâncias e indignação, fixando-me no objetivo de produzir registros claros e imparciais de argumentos e visões. 


\section{A noite na Praia de Iracema, a prostituição e o turismo sexual segundo moradores do circuito turístico de Fortaleza}

Esta tentativa de analisar interpretações e posicionamentos de pessoas que residem na Praia de Iracema e bairros vizinhos foi inspirada nas considerações de Geertz (1997) sobre o "senso comum". Para o autor, o "senso comum" constitui um tipo de conhecimento baseado em símbolos compartilhados por uma comunidade determinada. Assim como a ciência e a religião, o senso comum funcionaria como um sistema que fornece explicações com base em um repertório de noções, não devendo ser tomado como algo que aprendemos casualmente, mas como um conjunto organizado de pensamento deliberado. Com o passar dos anos, opiniões tomadas da experiência vão se tornando ideias afirmadas, que se estruturam como uma espécie de catálogo e vêm funcionar como referência para visões e argumentos. (Geertz, 1997). Esta concepção geertziana de "senso comum” é relevante para a compreensão e contextualização das falas seguintes. A intenção é colocar em relevo narrativas, argumentos e visões que expressam um certo "senso comum" disseminado entre moradores dos três bairros mencionados sobre as noites da Praia de Iracema, seus personagens e dinâmicas.

A reprovação aos encontros entre homens estrangeiros e mulheres locais ensejados pelo turismo sexual e a prostituição na P.I. foi unânime entre os entrevistados. Algumas destas pessoas entendem que a forma explícita como se desenvolve o comércio do sexo no bairro implica prejuízos morais e constrangimentos às "famílias" da cidade, constituindo um "mau exemplo" para os jovens. Ao ser indagada se frequenta os bares e restaurantes da Praia de Iracema, Rejane, de 46 anos, residente e proprietária de uma "boutique" no Meirelles, salientou-me que:

Não tem mais a menor condição da gente frequentar. Eu jamais saio da minha casa, com meu esposo e meus filhos para jantar ali. É você jantando com sua família no restaurante e do lado de fora as prostitutas fazendo ponto. É muito constrangedor (...). Imagina uma mãe levar seus filhos para aquele ambiente, o quê que os filhos não vão pensar? Que é normal. Se minha mãe tá me trazendo para cá vê isso é porque é isso aqui é o certo.

$\mathrm{Na}$ fala de Rejane é enfatizada a preocupação com os desdobramentos negativos da visibilidade da prostituição na P.I. sobre a educação dos seus filhos. Também para Edwiges, de 75 anos, professora do Ensino Médio aposentada e moradora da Praia de Iracema, a presença disseminada de garotas de programa no bairro é negativa: 
É muita safadeza o que acontece por aqui minha filha, não sei onde tá a falta de vergonha maior se é nessas mulheres da vida ou nesses homens que vêm do outro lado mundo atrás delas. Não se vê respeito com ninguém (...). Elas andam quase nua na rua, vivem se agarrando com os homens sem pudor. (...) Eu nunca imaginei que um dia fosse conviver com isso.

A apreciação de Edwiges revela temor diante de práticas que considera indicativas de uma transformação de valores em curso. Situações presenciadas e das quais tomou conhecimento sinalizam o enfraquecimento de referências valorativas e comportamentais que ela acredita ser imprescindíveis à vida social. Considerando que a prostituição atrelada ao turismo no contexto da Praia de Iracema, tem nos estrangeiros seus principais clientes, alguns moradores tendem a enfatizar a condição de "forasteiros" destes homens, interpretando seus interesses sexuais pelas mulheres locais como um desrespeito à cidade $\mathrm{e}$ ao país. Uma fala ilustrativa desta visão é a de Emiliano, um comerciante de 58 anos, morador da Praia de Iracema desde 1967:

Tudo isso que acontece no nosso bairro é uma afronta às famílias, ao povo de bem de Fortaleza e a todos os brasileiros. Vem um batalhão de homens para cá e age como se a cidade fosse um cabaré. A gente sabe que se depender da prefeita e do governador isso aqui é um cabaré a céu aberto. (...) Essa situação do turismo sexual, você me desculpe a expressão, é como se a cidade estivesse toda de pernas abertas para esses gringos. (...) Todo lugar que você chega, tem um estrangeiro com uma neguinha.

O termo "neguinha", usado por Emiliano para se referir a jovens negras ou mulatas que se envolvem com estrangeiros, embora constitua uma denominação pejorativa e racista, suscetível a encaminhamentos jurídicos, é recorrentemente utilizado por moradores dos três bairros mencionados. Para se referir aos estrangeiros que frequentam a P.I., não raro recorrem ao termo "gringo" que, de acordo com Blanchette (2011), é utilizado em todo país e pode ser tomado de forma ética ou êmica: "Como categoria nativa, é um rótulo brasileiro não pejorativo para estrangeiros cujo sotaque nativo atrapalhe sua fluência em português. Como categoria de análise, remete a certo tipo de "outro" que se aproxime e esteja presente entre nós.” (Blanchette, 2011: 61).

Narrativas e posicionamentos apresentados pelos entrevistados sugerem que a reprovação à presença de "gringos" na cidade acompanhados de mulheres locais decorre do seguinte raciocínio: ao se envolverem com homens que vêm à Fortaleza para frequentar casas noturnas e consumir serviços sexuais, atitude tomada como desrespeitosa à cidade e 
aos seus moradores, as garotas de programa estariam a um só tempo, colocando-se em posição de inferioridade e submetendo os fortalezenses a constrangimentos e humilhação. A fala de Joana, de 34 anos, designer de joia, moradora da Praia de Iracema, elucida a referida visão:

Essas aqui da P.I. são tudo prostitutas. Uma moça de família não se envolve com esses turistas que vêm aqui não. Eles são os faxineiros, pedreiros, porteiros, padeiros lá na Europa. Se você for ver é um povo sem cultura. (...) Uma mulher que dar cabimento para esses homens que vem para os puteiros daqui ou é muito pobre e precisa da esmola dele, ou é uma puta mesmo, sem amor próprio. (...) E essas putinhas expõem todo mundo, é por causa delas que os gringos dizem que todas as mulheres de Fortaleza são putas.

Ao reprovar as jovens que se envolvem com estrangeiros, Joana se mostra preocupada com a imagem da população feminina da Fortaleza e, a rigor, com a sua própria imagem. Criticando estas mulheres que denomina "putinhas", ela revela um acintoso preconceito de classe. Se em sua fala é proeminente a reprovação e suspeição ante as mulheres que se envolvem com os turistas. Samara, de 36 anos, moradora da Aldeota, proprietária de um requintado restaurante, chama a atenção para a conduta dos homens que protagonizam o turismo sexual.

Esses estrangeiros da Praia de Iracema são todos mal intencionados, eles não vêm aqui para conhecer o que tem de bonito no nosso estado não. Eles vêm atrás de mulher fácil. Eles não estão interessados nas praias, na nossa história, na nossa cultura, eles não querem saber disso não. Uma pessoa que tem cultura se quer conhecer alguém no lugar vai procurar uma moça de nível. (...) Eles só procuram as neguinhas pobres que não tem uma boa alimentação, não tem a chance de ter um emprego bom. Eles querem essas coitadas porque elas se submetem a qualquer tipo de coisa.

Assim como Joana, Samara demonstra preconceito em relação à condição social das jovens locais que se relacionam com estrangeiros. Sua fala chama a atenção para assimetrias nestas relações, atribuindo submissão e fragilidade às mulheres que chama de "coitadas". Na fala de quase todos os entrevistados, foi evidente a percepção das relações entre "gringos" e mulheres locais como "problema" ou "explicitação de problemas sociais". Neste sentido, a fala de Lázaro, de 34 anos, morador da Aldeota, agente da Polícia Rodoviária Federal, é ilustrativa: 
O turismo sexual não é uma coisa localizada na P.I., o problema é que se espalha. Hoje em todo lugar de Fortaleza, a gente vê aquele casal clichê, um lourão, muitas vezes, um velhão, com uma menina pobre. Eu acho muito triste ver isso, mas é a realidade. A gente encontrar o tempo todo um estrangeiro e uma neguinha é para a gente se lembrar desse problema da prostituição na nossa cidade, onde muitas pessoas não têm oportunidade. Nossas meninas pobres precisam ter oportunidade de estudo e trabalho para não se submeter a esse tipo de coisa que é tão feio para a cidade e tão triste para elas.

Nas conclusões de Lázaro há pressupostos não tão consensuais assim: as relações entre jovens locais e estrangeiros seriam necessariamente negativas e humilhantes para as primeiras; a necessidade material levaria estas mulheres a se envolverem com estrangeiros. Sendo assim, se Fortaleza fosse uma cidade onde jovens de baixa renda tivessem oportunidade de estudar e ingressar no mercado de trabalho não haveria o casal que ele considera "clichê". Em seu relato, além de relacionar o interesse das moças por estrangeiros a privações materiais, Lázaro, estabelece um recorte racial no perfil destas mulheres, que são apresentadas como "neguinhas".

Também Fernanda de 24 anos, graduada em arquitetura e urbanismo, moradora do Meireles, considera negativas e prejudiciais as relações de jovens locais com estrangeiros:

Eu fico muito triste, acho que é a total degradação do ser humano. Eu não entendo como é que uma mulher transa com um homem que a vê como um ser menor, que usa seu corpo para sexo, aceitar isso é a degradação do ser. Essas mocinhas precisam ser conscientizadas, muitas delas são menores de idade, esses homens destroem a autoestima delas. Eles submetem nossas meninas a uma condição humilhante, além de degradá-las como seres humanos eles destroem a cidade delas. Uma das coisas mais importantes para um ser humano é relação com o espaço, ter o seu lugar, a sua cidade. Esses homens não sabem da nossa história, não entendem que a Praia de Iracema é o coração de Fortaleza. Pra eles aquilo ali não tem valor nenhum. (...) Eles retiram a dignidade e a autoestima das meninas e prejudicam a cidade delas. Fortaleza hoje é conhecida no mundo todo como um puteiro.

Afirmando que a Praia de Iracema é "o coração de Fortaleza”, Fernanda acredita que turistas estrangeiros, ao estabelecer relação com fins estritamente sexuais com moças de baixa renda da cidade, negam a condição humana destas mulheres e comprometem a imagem e a memória da cidade. Embora a antipatia disseminada na fala dos entrevistados a "gringos", "neguinhas" e ao "casal clichê" formado por estes personagens ganhe inteligibilidade pela já mencionada condenação moral que a prostituição tende a desencadear nos mais diversos contextos, há indícios de que o lugar simbólico de "vitrine" e "coração da cidade" atribuído à Praia de Iracema também explica a animosidade de 
moradores da orla e bairros vizinhos em relação à presença de estrangeiros e suas acompanhantes nativas no bairro. Não se trata, simplesmente, das pessoas por mim entrevistadas considerarem o comércio do sexo uma prática moralmente inaceitável, pois a prostituição está disseminada em vários bairros da capital do Ceará, sendo os homens residentes na cidade consumidores assíduos deste serviço sexual (Diógenes, 2008). Além da reprovação moral à atividade prostitutiva, existe outras motivações para a referida antipatia.

A Praia de Iracema costuma ser significada por moradores de Fortaleza com diferentes níveis de renda e residentes em diferentes bairros como "cartão postal" da cidade, além de ser uma região onde elites econômicas e intelectuais locais circulavam em um passado recente. Durante todo o século $\mathrm{Xx}$, as referências usuais ao bairro foram de "lugar paradisíaco", "refúgio dos intelectuais", "ponto de encontro de poetas", "reduto da boemia", dentre outras denominações.

A região da orla, que atualmente corresponde à Praia de Iracema, até o início do século Xx, abrigava uma vila de pescadores e era conhecida como Praia do Peixe. Ainda na primeira metade do século Xx, famílias abastadas da cidade construíram casas de veraneio na região, posteriormente surgiram hotéis e clubes (Bezerra, 2009). Por volta de 1960, o lugar já havia se consagrado na imprensa local como "berço cultural da cidade", movimentado por uma assídua boemia intelectualizada, celebrada entre moradores do bairro. Atendendo a reivindicações de poetas e jornalistas locais, a Prefeitura Municipal trocou o nome "Praia do Peixe" por "Praia de Iracema", em homenagem à heroína do romance de Jose de Alencar (Bezerra, 2009).

Em meados dos anos de 1970, período em que o país era governado pela ditadura militar, o bairro se tornou refúgio de militantes e grupos políticos de esquerda contrários ao regime autoritário. Estes personagens se encontravam em saraus, jantares e serestas da P. I. Nas décadas seguintes, a prefeitura e o governo do estado investiram elevada quantidade de recursos em equipamentos de lazer, estimularam o uso turístico e a exploração imobiliária no bairro. Desde então a Praia de Iracema deixa de ser apenas a "virgem desnudada pelo sol" dos poetas cearenses e se torna uma espécie de "vitrine" da ensolarada Fortaleza, exibida por seus moradores aos visitantes de outros países ou de outras regiões do Brasil (Bezerra, 2009).

Nos início dos anos 2000, a P.I. constituía o principal polo de lazer da cidade, abrigava dezenas de bares e restaurantes, atraindo grande quantidade de moradores e turistas. Neste período, já se verificava a circulação de garotas de programas e estrangeiros interessados em seus serviços nas ruas, bares e restaurantes do bairro. A disseminação da 
atividade prostitutiva, e de estabelecimentos que estimulavam "encontros" e intercâmbios sexuais entre mulheres locais e turistas fizeram com que a Praia de Iracema se tornasse estigmatizada e considerada "zona de prostituição". Na medida em que aumentava a circulação de estrangeiros e garotas de programa no bairro, tornava-se menor a quantidade de moradores, sobretudo das classes média e alta, frequentando bares e restaurantes do bairro. Este fenômeno se tornou conhecido na cidade como a "a invasão dos gringos e das putas na Praia de Iracema" e teve o efeito de modificar os usos e significados concedidos ao lugar, afastando àqueles que parte dos meus entrevistados denominam "pessoas de bem" e "famílias". Portanto, a reprovação à prostituição e ao envolvimento de mulheres nativas com "gringos" nas noites da Praia de Iracema se torna inteligível pela história do bairro, em seus usos e dinâmicas anteriores à disseminação da prostituição ou pelo lugar simbólico que a população atribui à P. I., percebida como relevante para a memória coletiva da cidade (Porto Neto, 2012).

Alguns relatos de moradores e ex-moradores da Praia de Iracema são carregados de nostalgia, sendo possível vislumbrar a retórica que Bezerra (2009) denomina "alegoria do Adeus". São recorrentes narrativas que se referem a uma época apresentada como gloriosa, marcada pela eloquência de sociabilidades boêmias e cenários bucólicos percebidos como extintos (Bezerra, 2009). A fala de Clara, artista plástica de 42 anos, ex-moradora do bairro, é ilustrativa deste saudosismo:

É triste ninguém tomar uma providência, a prostituição e os abusos que acontecem aqui há mais de uma década, todo mundo sabe que prejudica a cidade e o poder público não consegue resolver o problema. Eu sinto até vontade de chorar quando eu lembro o que já foi isso aqui (...) tinha uma rotina muito sadia, de jovens, pessoas idosas, crianças acompanhadas de seus pais que vinham ver o por do sol. À noite nos barzinhos todo mundo se encontrava. (...) Tudo desmoronou com a invasão dos gringos, eles vêm aqui em busca de sexo, de consumir o Brasil exótico. Eu não acho que seja tão absurdo isso não. O problema é que quando eles chegaram, quem frequentava aqui foi embora: os artistas, o pessoal da universidade, nossas ruas ficaram um deserto. Eles vieram só acabar com o nosso cantinho. Era tão bom morar aqui.

A percepção dos entrevistados sobre as mulheres que se envolvem com "gringos" é dúbia. A um só tempo as consideram "vítimas" e "culpadas" pelo que entendem como “decadência da Praia de Iracema”, manifesta na disseminação de práticas como prostituição e tráfico de drogas no bairro. As jovens locais são apresentadas, por um lado, como vítimas de homens que as submetem a situações humilhantes, por outro lado, também aparecem como "invasoras": teriam usurpado o bairro dos seus moradores e frequentadores, 
degradando-o moralmente e o tornando impróprio para o lazer "das pessoas de bem". Além de causarem prejuízos materiais e simbólicos à P.I., estas mulheres seriam "culpadas" pela "má fama" de Fortaleza em escala internacional, uma vez que a cidade teria se tornado mundialmente conhecida como polo de prostituição.

Se há ambiguidade em relação às jovens locais que se envolvem com turistas estrangeiros nas avaliações de moradores da Praia de Iracema, Meireles e Aldeota, quando se trata dos "gringos" não há hesitação, estes homens são invariavelmente percebidos como vilões. De acordo com os entrevistados, os estrangeiros tiram proveito das desvantagens econômicas e sociais vivenciadas por mulheres nativas, procuram estas jovens para fins estritamente sexuais, constrangem os moradores de Fortaleza e tornam imprópria a frequência de "famílias" e "pessoas de bem" em determinados espaços do circuito turístico.

\section{"Encontros" entre "gringos" e mulheres locais nas noites da Praia de Iracema}

Nas décadas do 1980 e 1990, pesquisas e reportagens assinalam uma expansão no turismo sexual. Antes concentrado no continente asiático, o fenômeno passa a abranger cidades litorâneas da Américas Latina e do Caribe (Truong, 1990; Kempadoo e Doezema, 1998; Mullings, 1999). Em Fortaleza o turismo sexual passa a ser tratado como "problema social" por gestores e veículos midiáticos no início dos anos 2000. Sendo a capital brasileira mais próxima da Europa, a inauguração dos primeiros trechos de voos diretos, ligando a cidade ao velho continente, desencadeou a vinda massiva de homens estrangeiros. Buscando atrair estes turistas, proliferaram estabelecimentos que promoviam ou estimulavam a prostituição na Praia de Iracema. A estruturação e a visibilidade de um "mercado do sexo" de dimensões transnacionais no bairro afastou moradores de Fortaleza e turistas não interessados em pagar por serviços sexuais na cidade (Porto Neto, 2012; Aquino, 2015).

Atualmente, a Praia de Iracema persiste como uma zona de prostituição. As mulheres que transitam nas noites e madrugadas do bairro em sua quase totalidade são garotas de programa. Uma parte destas tem no comércio do corpo atividade exclusiva, sendo recorrente que também se prostituam em outros redutos da capital. Ribeiro (2013) destaca a alternância de algumas mulheres entre a P.I. e o Clube do Whiski, uma sofisticada casa de prostituição localizada na Aldeota, frequentada por políticos e empresários da cidade. Há também as que possuem outras ocupações além da prostituição, algumas são 
empregadas domésticas, outras estão inseridas no comércio local, sobretudo em lojas de roupas e salões de beleza.

Nos bares e boates do bairro, ${ }^{4}$ as mulheres costumam usar roupas curtas e coladas ao corpo, sandálias e sapatos com salto alto, tendo os rostos cuidadosamente maquiados, dançam e requebram com olhos fixos nos homens que buscam seduzir. No que diz respeito à etnia, há uma considerável diversidade. $\mathrm{Na}$ seção anterior deste texto, alguns entrevistados utilizaram o termo "neguinha" para designar jovens que se envolvem com estrangeiros, sugerindo que se tratam invariavelmente de pretas e pardas. No cotidiano noturno da Praia de Iracema, todavia, circulam mulheres com diferentes tons de peles, sendo expressiva a presença de prostitutas brancas. Considerando que o estereótipo internacionalmente difundido de mulheres brasileiras as associa a biótipos mestiços, indaguei algumas garotas de programa se por serem brancas não ficariam em desvantagem em um "mercado do sexo" voltado a turistas estrangeiros e pautado na exotização da sexualidade nacional (Gabrielli, 2011). Minhas interlocutoras garantiram que não se sentem preteridas e argumentaram que as expectativas de estrangeiros em relação às brasileiras estão menos relacionadas a padrões raciais que a traços culturais. De acordo com suas falas, estes homens associam às mulheres locais características e habilidades como danças sensuais, apetite sexual, carinho e cuidado com o sexo oposto, alegria, simplicidade e "bom coração".

Nas casas noturnas da Praia de Iracema, a aproximação entre prostitutas e clientes ocorre sob a forma de "paquera" e pelo que pude perceber não se diferencia muito de outros tipos de interação entre homens e mulheres não mediadas pelo comércio do corpo. Em tais ocasiões, as conversas não se restringem a negociações de valores e condições do "programa", algumas vezes esse assunto nem chega a ser abordado. Os homens costumam se aproximar de várias mulheres nas boates antes de escolher sua acompanhante daquela noite. Não raro, os interesses dos estrangeiros vão além da relação sexual, envolvendo a busca por uma companhia ou cicerone durante sua estadia no Brasil. Nestes casos, as jovens que circulam nos bares e boates do bairro acabam por lhes transmitir informações sobre praias do litoral cearense e brasileiro, hospedagens, gastronomia local, datas de festas populares, saberes disseminados entre os moradores da cidade, mas desconhecidos dos turistas.

Mesmo constituindo uma modalidade de intercâmbio econômico, estes "encontros" entre "gringos" e mulheres locais envolvem elevado teor de sedução, afeto e curiosidade mútua. De acordo com algumas das minhas interlocutoras de campo, 
os "gringos" costumam perguntar sobre suas condições de vida, relações com parentes próximos, se já foram casadas e se têm filhos. As mulheres, por sua vez, querem saber sobre as rotinas destes homens em seus países de origem, perguntam-lhes sobre o tamanho de suas casas, os pormenores das mobílias, os modelos de seus carros. As diferenças culturais e de condições sociais e econômicas entre ambos costumam render longas conversas e explicações detalhadas sobre o país e o modo de vida de cada um. Tais interações envolvem variadas modalidades de trocas e assumem diferentes desdobramentos, sendo mediadas por emoções e artifícios diversos. As peculiaridades destes "encontros" acabam por se manifestar nas formas de proceder à cobrança, pela mulher, e de efetuar o pagamento, pelo homem. Algumas jovens que se prostituem na P.I. afirmaram que os pagamentos por seus serviços variam de acordo com a situação e as características daqueles que as requisitam. Gigi, uma garota de programa de 22 anos, afirma que quando se trata de homens feios ou que dão sinais de não ter altas quantias para gastar no Brasil, ela procura acertar o valor e a duração do "programa" com antecedência. Por outro lado, quando o "gringo" é bonito ou parece ser um homem rico, Gigi protela a cobrança e tenta suscitar novos encontros. Em muitos casos, presentes substituem valores em espécie. Nas situações em que um encontro inicial se estende por dias ou semanas, os ganhos econômicos da mulher na relação não resultam de uma cobrança direta associada à estipulação de um valor. As expectativas por recompensa material costumam ser explicitadas por meio de relatos que enfatizam as dificuldades econômicas marcantes em suas vidas, quase sempre ressaltam a pobreza de seus familiares. Quando são mães solteiras, mencionam os filhos e as dificuldades de sustentá-los. Tais relatos, que colocam em relevo privações materiais, costumam sensibilizar os estrangeiros que lhes presenteiam com roupas, telefones celulares, joias e até mesmo com carros e imóveis. Muitos "gringos", depois de um programa ou de uma sucessão de programas, ao voltarem aos seus países, mantêm contato com mulheres que circulam na P.I. pela internet, enviando-lhes presentes e, eventualmente, dinheiro em espécie. Para designar esse tipo de intercâmbio, que não implica em regularidade nas contribuições, nem em vínculos monogâmicos, minhas interlocutoras costumam utilizar o termo "ajuda". Não raro ouvi declarações como esta: "a gente não tem compromisso, mas ele me ajuda".

Com base em sua etnografia pioneira na Praia de Iracema, no início dos anos 2000, Piscitelli (2011) ressalta o uso da categoria "ajuda" entre suas colaboradoras de pesquisa, enfatizando que se trata de uma "noção amplamente difundida nas classes médias e baixas do Brasil", em referência a "contribuições econômicas que, embora consideradas 
relevantes, não constitui a principal fonte de recursos para a sobrevivência. (...)a ajuda seria trocada por sexo, não necessariamente dissociado de afeto" (Piscitelli, 2011:09). A autora esclarece a diferença entre "programa" e "ajuda": "Se a ideia de programa evoca um contrato de serviços, a ajuda inserta uma tradição de intercâmbios hierárquicos, remete a noção de amparo, cuidado e afeto que se expressam em termos de contribuição para a sobrevivência econômica" (Piscitelli, 2011:09).

Pesquisando prostitutas no Pelourinho em Salvador, Bacelar (1982) já chamava a atenção para diferentes modalidades de trocas sexuais e econômicas vivenciadas por estas mulheres. Além de clientes que pagavam valores definidos pela relação sexual, elas também recebiam em suas casas, homens que não lhes faziam pagamento convencional, mas “ajudavam-nas" com mantimentos e algumas vezes com dinheiro (Bacelar, 1982). Em seu trabalho com a prostituição de rua em Porto Alegre, Fonseca (1996) assinala que suas interlocutoras recebiam não só dinheiro, mas também presentes e benefícios em troca de sexo. A autora destaca, ainda, mulheres da mesma classe social das prostitutas que, embora não fizessem "programas", mantinham intercâmbios sexuais e afetivos com homens pautados na "ajuda” (Fonseca, 1996).

Evidencia-se, portanto, que a noção de "ajuda" está difundida em diferentes cidades e contextos de prostituição no país. Piscitelli (2011) enfatiza a "longa história de interpenetrações entre economia e sexualidade no Brasil, expressa na convivência entre diferentes modalidades de intercâmbios sexuais e econômicos” (Piscitelli, 2011:12). Se o cenário da Praia de Iracema, por constituir um "mercado do sexo" de dimensões transnacionais, evoca "programas" sob a forma de contratos explícitos de intercâmbio de sexo por dinheiro, subjacente ao contexto do turismo sexual existe toda uma tradição de trocas sexuais e afetivas pautados na "ajuda". Os estrangeiros, mesmo quando têm expectativas de relações baseadas em trocas diretas de dinheiro por sexo, costumam ser introduzidos em intercâmbios caracterizadas pela confusão entre serviços sexuais e afetividade (Piscitelli, 2011). As garotas de programa atuantes na P.I. tendem a descolar suas atividades de uma lógica marcadamente comercial de sexo instrumental, transformando-as em relações mais duradouras pautadas por dádivas e envolvimento emocional.

Em três anos de recorrentes incursões etnográficas na Praia de Iracema, nunca ouvi uma prostituta se referir aos "gringos" com quem mantêm intercâmbios econômicos e sexuais, utilizando o termo "cliente". Dependendo das características do encontro e dos interesses da mulher, estes homens são chamados de "namorado", "esquema" ou "amigo". A prestação de serviços sexuais não exclui a possibilidade de amor romântico, em muitas 
situações parece propiciá-lo. Ouvi muitos relatos de paixões fulminantes. Não raro, programas se transformam em relações pautadas na "ajuda" e mesmo em casamentos.

Pesquisando a prostituição vinculada ao turismo sexual no Rio de Janeiro, Silva e Blanchette (2005) se deparam com contextos similares aos que verifiquei na P.I. e assinalam a dificuldade em definir o que é um programa: "Embora uma parte dos programas envolvam pagamento em dinheiro, uma parte não envolve pagamento em dinheiro e chega a ter duração indeterminada, podendo resultar em casamento" (Silva e Blanchette, 2005: 27). Em outras partes do mundo, a transnacionalização dos mercados do sexo tem se efetivado a partir de trocas expressivamente mercantilizadas. No sudeste asiático, por exemplo, de acordo com Lim (2004) os pagamentos que estrangeiros efetuam a mulheres nativas por serviços sexuais, ocorrem no âmbito de uma organizada indústria do sexo (Lim, 2004). No Brasil, entretanto, destacam-se modelos mais informais de vivenciar tais "encontros".

A trajetória de Vanda, atualmente com 35 anos, é ilustrativa de intercâmbios sexuais e econômicos entre "gringos" e jovens locais nas noites da Praia de Iracema, que resultam em casamentos:

Eu trabalhava em uma farmácia aqui perto. No começo, eu vinha aqui de vez em quando, mas eu não fazia programa não. (...). Naquele tempo não era fácil se comunicar como hoje, (...) era muito triste porque eu me apaixonava e perdia o contato. De tanto sofrer eu pensei: quer saber de uma coisa, eu vou é cobrar, vou viver o momento e ganhar dinheiro. Aí eu já tava endurecendo, quando apareceu o Javier. Ele tava passando um mês no Brasil, daqui ia pro Rio de Janeiro. Depois de três dias a gente se encontrando ele perguntou se eu não queria ir com ele pro Rio de Janeiro. Eu era pobre, não tinha costume de viajar, fiquei morta de feliz. Lá no Rio, ele perguntou se eu não queria casar com ele, ai nós fomos logo ajeitando os papéis pra casar e viajar. Ele foi, com três meses ele voltou e nós casamos e eu fui embora com ele. Isso já faz oito anos.

No dia em que a conheci, Vanda estava em um restaurante da Praia de Iracema, acompanhada de dois amigos de Javier, seu esposo, que chegaria em Fortaleza na semana seguinte. Ela se mostrou satisfeita por viver em Paris e disse que é feliz com o marido francês. Vanda tem filhos, casa própria e é assistida pelo sistema de previdência social francês.

Para alguns moradores da orla de Fortaleza, como visto na seção anterior, as relações entre "gringos" e mulheres locais são percebidas como um tipo de sacrifício ao qual estas jovens se submetem por não terem acesso à educação, nem oportunidades de 
emprego. É possível que a busca por superar privações materiais seja a motivação principal de uma parte delas, entretanto não parece ser a única. Afirmações e narrativas que acessei durante o trabalho de campo me levaram a acreditar que também há interesses subjetivos e atração física por parte das jovens locais nestas relações. Namoradas e esposas de "gringos" com quem desenvolvi diálogo, afirmaram-se emocionalmente envolvidas com seus companheiros. Além de ressaltarem as quantias em dinheiro e presentes que recebem, elogiaram o tipo físico e os modos afetuosos destes homens. Os europeus que frequentam a P.I. foram mencionados como "generosos", "carinhosos" e "lindos" por minhas interlocutoras. Mesmo nos que não são considerados bonitos, foram ressaltados traços físicos que os tornariam atraentes. Entre os atributos mencionados estão olhos claros, tórax e abdomens esculpidos pela prática de esportes.

Durante o primeiro semestre de 2012, a crise econômica sofrida pelo velho continente foi alardeada na mídia brasileira, disseminando entre garotas de programa atuantes nas noites da Praia de Iracema o receio de uma acintosa queda na quantidade de europeus em férias no Brasil. Surpresa diante do interesse daquelas mulheres pela economia mundial, um dia abordei o assunto com Selminha, que tem 24 anos e faz programas desde 2008. Na ocasião, ela externou algumas angústias:

Selminha - Mulherzinha eu tou com muito medo dessa crise na Europa(..).

Jania - Selminha sempre que tem alguém ficando pobre no mundo, tem também alguém ficando rico. (...)Se os europeus deixam de vir, daqui a pouco vêm os indianos, chineses, eles é que são os ricos do momento.

S - Mulherzinha vira essa boca pra lá, eu não quero chinês não.

$\mathrm{J}$ - Por que Selminha?

S - Eles são muito feios, e sem sal, eu não me animo não.

$\mathrm{J}$ - E quem é que você acha bonito? Os italianos?

S - É, os italianos são muito bonitos.(...) O jeito de falar é que eu acho mais bonito, fico louca, chama a gente de "carino", "amore", "bambina". Porque bonito de verdade é holandês, esses são os mais bonitos, o rosto mais afilado, os olhos lindos, agora italiano é mais charmoso, fala de um jeito que eu adoro: "va bene", "ragazza", "vita mia", eu acho muito lindo.

$\mathrm{J}$ - Ah tá certo, então você tá com medo de ficar sem os italianinhos?

$\mathrm{S}$ - Tou mesmo, italiano, português, espanhol tudo eu gosto. Mulher, se eles não tiver dinheiro para vir cá, eu vou bater lá na Europa. Tem uma prima minha que é casada com um português eu vou pra lá. Eu gosto é de europeu, brasileiro eu já não gosto muito, e esse chinês que você tá dizendo eu não quero nem na hora da morte.

$\mathrm{J}$ - Então você prefere um europeu pobre a um chinês rico?

S - Mulher, prefiro, porque o europeu pobre, não é pobre como os pobre daqui não, eles têm casa para morar, têm ajuda do governo, têm uma vida boa, têm carro, têm tudo o que a gente aqui acha que é vida de rico. (...) Para o nível de vida da gente aqui, os pobre de lá são classe média. 
A fala da minha interlocutora, além de revelar um relativo conhecimento sobre distribuição de renda e previdência social na Europa, evidencia sua preferência estética e subjetiva por homens europeus, que não se explica somente pelos ganhos econômicos resultantes do envolvimento com eles, mas por considerá-los bonitos e carinhosos. Tais impressões também se verificam entre fortalezenses solteiras que não se prostituem. Em minhas incursões etnográficas nas noites da Praia de Iracema, encontrei mulheres de diferentes classes sociais que não se assumiam garotas de programa. Embora fossem ao bairro exclusivamente para conhecer "gringos", as motivações desta procura seriam subjetivas e estéticas. Sandra, uma pedagoga de 33 anos, explicou-me:

Eu venho aqui porque a gente conhece pessoas maravilhosas, esses homens de fora são lindos, educados e se apaixonam. Você com certeza sabe que na nossa cidade não tem homem, só tem mulher e viado. Os homens daqui, além de ser feios e baixinhos, "se acham" (...). Só ser feio não é defeito não, o problema é que eles são feios, se casam com mulher bonita e ainda trai...

Apresentando os homens locais como feios, infiéis e escassos, Sandra vê nos estrangeiros uma alternativa conjugal e afetiva. Mesmo não se destacando entre dezenas de garotas de programas no bairro, também circulam na P.I. outras fortalezenses como Sandra, que não estão dispostas a ingressar na prostituição, mas têm expectativa de envolvimento sexual e subjetivo com "gringos". Sem afirmar ou questionar a autenticidade dos sentimentos destas mulheres, garotas de programas ou não, que anseiam por namoros e casamentos com estrangeiros, é preciso destacar que tais homens, quase sempre brancos, oriundos de países ricos e que assumem o papel de provedores, acabam por ser associados à imagem de "príncipe encantado", propagada em estórias infantis e reproduzida em roteiros de telenovelas e filmes direcionados, sobretudo, ao público feminino (Rosa, 1999). Em vez de repeli-los, como acreditam alguns moradores da orla entrevistados, jovens nativas tendem a desejá-los, associando-os a conquistas e realizações materiais e subjetivas.

Embora tenham visões predominantemente positivas sobre vínculos afetivos e conjugais com "gringos", também são conhecidas por garotas de programas atuantes na P.I. narrativas de relacionamentos entre mulheres locais e homens europeus marcadas por violências e conflitos. Ouvi relatos de histórias protagonizadas por minhas interlocutoras, ou por familiares e amigas destas, em que a esposa foi espancada pelo marido. Também soube de casos em que a mulher, residindo na Europa, ao pedir o divórcio e decidir voltar ao Brasil, perdeu a guarda e o direito de ver os filhos. Apesar da empolgação com a 
possibilidade de casar e ir morar no exterior, ao contrário de deslumbramento e falta de disposição para cogitar desfechos negativos, pareceu-me bastante difundida entre minhas colaboradoras de pesquisa a consciência de que suas relações com "gringos" são perpassados por assimetrias de gênero e de classe. Tal percepção não parece dissuadi-las do que consideram "vantagens" em eventuais namoros e casamentos. Quando lhes chamava a atenção para os riscos de se unir com homens praticamente desconhecidos e de ir morar em países distantes, ouvia argumentos como os de Scheila, uma garota de programa de 23 anos:

Eu sei que posso quebrar a cara indo, mas também posso quebrar ficando? Eu sei que posso apanhar por lá, mas se ficar com um brasileiro também posso apanhar, é só o que acontece. Se eu apanhar lá eu venho embora, não precisa nem de dinheiro pra passagem eu posso ser deportada, volto pra Fortaleza de graça.

Quando confrontadas com possibilidades de desfechos conflituosos em seus projetos de relacionamentos com "gringos", minhas interlocutoras enfatizaram outros ganhos e vantagens no convívio com estes homens, tais como o consumo gratuito de bebidas e drogas. Também foram apresentadas como experiências marcantes, almoços e jantares em restaurantes sofisticados de Fortaleza, onde se sentiriam constrangidas se não estivessem de braços dados com homens que os garçons e o público destes estabelecimentos tendem a considerar de "boa aparência" e com recursos para frequentar o lugar.

Eventos e narrativas a que tive acesso no campo reiteram a observação de Piscitelli (2003) de que uma parte das mulheres que circulam na Praia de Iracema vivenciam a prostituição como estratégia migratória, vendo nos intercâmbios sexuais e afetivos com "gringos" a possibilidade de residirem na Europa. Entre minhas interlocutoras, todas demonstraram fascínio em relação a viagens ao exterior, algumas já tiveram oportunidade de conhecer a Europa, estas, durante nossas conversas, entoavam expressões em italiano, espanhol e inglês. Além de narrativas, informações e gestuais acionados como evidência de traquejo em roteiros internacionais, foram exibidos objetos como iPhones, iPads, bolsas, sapatos e óculos escuros de grifes como Versace, Prada e Gucci.

Oriundas da periferia de Fortaleza, ao frequentarem as noites da Praia de Iracema, espaço por onde circulam homens de variados países e continentes, o cenário internacional passa a fazer parte da rotina de muitas garotas de programas. Conforme ilustra a fala de Vanessa, de 24 anos, uma parte destas jovens têm consciência da relação entre a atividade que desenvolvem e os desígnios da conjuntura econômica internacional: 
Olha a gente tem muita sorte de ter essa quantidade de gringo por aqui, pois lá fora o bicho tá pegando, muitos países ainda não conseguiram superar a crise de 2008. Aqueles países nórdicos, Suíça, Finlândia, Noruega, a crise não chegou lá não, mas esses mais de baixo como Itália e Portugal (...) o negócio lá tá feio. Você viu não é? Na Itália, a crise também tá séria, o Berlusconi renunciou e tudo. Esses caras que mesmo com crise, tão vindo para o Brasil, é porque vive bem lá, não sentiram a crise no bolso.

Até quando nunca saíram do Brasil e jamais desenvolveram relações duradouras com "gringos", o desempenho da economia mundial influencia amplamente o cotidiano de trabalho destas mulheres, pautando suas preocupações e conversas de rotina. As oscilações de mercados, valorização ou desvalorização do real, do dólar e do euro, índices de emprego e desemprego interferem diretamente na quantidade de "programas" que conseguem fazer a cada noite.

Há um repertório de conteúdos e modos de se portar que garotas de programa vão adquirindo no convívio com homens oriundos de diferentes países. Com base nas narrativas de algumas interlocutoras de campo, tenho observado que estes saberes não só as fazem se sentir desenvoltas e cosmopolitas, como têm lhes possibilitado ingresso formal no mercado de trabalho local, na condição de secretárias, representantes de vendas, atendentes, dentre outros postos. Lutiely, de 23 anos, contou-me que, habitando a região metropolitana de Fortaleza até os 21 anos, quando ingressou na prostituição, não conhecia a Praia de Iracema, nem outros bairros da orla. Depois que começou a fazer programas, interessou-se em aprender espanhol e inglês, iniciou seus estudos de línguas com livros achados no lixo, treinava a pronúncia nos dois idiomas nas noites da P.I. Um ano depois, ela garante que já se comunicava perfeitamente em inglês, habilidade decisiva para que conseguisse um emprego em uma casa de câmbio na Aldeota. Apesar de ter ingressado nesta ocupação formal, Lutiely não deixou de frequentar as boates da Praia de Iracema, ela almeja se casar com um italiano e viajar de férias a Paris.

Além de proporcionar a jovens prostitutas experiências de consumo às quais jamais tiveram acesso antes, namoros e casamentos com gringos costumam interferir na posição destas mulheres e de seus familiares nas assimetrias sociais e relações de poder no contexto local. Vejamos detalhes da trajetória de Francisca: em 2005, ela tinha 27 anos e trabalhava como empregada doméstica na residência dos Alves Vieira, no Meireles. Eventualmente, frequentava as noites da P.I. e fazia programas. Naquele ano, ela conheceu Derek, um norte-americano de 52 anos que passava férias em Fortaleza. Eles se casaram e Francisca 
foi morar em Boston com o esposo. Em sua residência nos Estados Unidos, ela já recebeu seus antigos patrões e chegou a hospedar Milena, uma das filhas do casal Alves Vieira, por 16 dias quando esta última fazia intercâmbio naquele país. Orgulhosa, Francisca, quando veio à Fortaleza em 2011, contou-me que saiu da condição de empregada da família e se tornou uma "amiga muito querida" dos Alves Viera, informou-me que tem sido convidada para festas e almoços por sua antiga patroa. Segundo ela, depois do casamento com Derek, suas redes de amigos em Fortaleza e na cidade do interior do Ceará, onde residem seus pais, foram expandidas.

Pessoas que nem me davam importância, agora querem amizade, perguntam como é nos EUA. (...) Lá no interior dos meus pais, nós ajudamos eles a abrir um comércio, hoje os comerciantes e suas mulheres, gente rica da cidade, trata a gente de igual pra igual, tem curiosidade, dizem que estou elegante.

Nos últimos anos, em decorrência da crise na economia mundial que afetou os EUA e a Europa, tem sido recorrentes que casais binacionais formados nas noites da P.I. optem por residir em Fortaleza, onde os esposos estrangeiros costumam investir no comércio. Além da convencional vantagem de casar com homens de condições materiais mais favoráveis que as suas, estas mulheres contam com outros motivos para se sentirem triunfantes. A escassez de homens em Fortaleza afirmada por Sandra tem sido amplamente divulgada na mídia local. Os últimos levantamentos do IBGE têm identificado descompasso entre a população masculina e feminina na cidade. Em 2014, foram verificadas 283 mil mulheres a mais que homens, diferença que corresponde a $7 \%$ dos habitantes de Fortaleza ${ }^{5}$. A difusão desta informação tem reforçado nas solteiras da cidade a impressão de que "está faltando homens". Neste cenário, ao se casarem com estrangeiros, garotas de programas que circulavam na P.I., além de passarem a ser positivamente avaliadas pelos regimes de moralidades dominantes na sociedade local, já que deixam de ser "putas" e se tornam "esposas", tornam-se "invejadas" por vastos segmentos de solteiras, simplesmente por terem conseguido um "marido", conquista tida como relevante e difícil de ser alcançada, dada a percepção disseminada de um desnível quantitativo entre homens e mulheres em Fortaleza, exposto nas estatísticas do IBGE.

Entre minhas colaboradoras de pesquisa verifiquei, portanto, avaliações predominantemente positivas sobre os estrangeiros que frequentam bares e boates da Praia de Iracema, que foram apresentados como generosos, bonitos e carinhosos. Mulheres que 
se prostituíram na P.I e, atualmente, são esposas de "gringos" teceram elogios aos seus cônjuges, afirmaram que são felizes e que suas vidas melhoraram com o casamento. As jovens garotas de programa que circulam nas noites do bairro, em sua maioria declararam que almejam se casar com um estrangeiro e ir morar na Europa. Mesmo cientes de que tais vínculos podem ter desfechos conflituosos e de que a situação econômica da Europa não está favorável como em décadas anteriores, consideram vantajosos intercâmbios econômicos e sexuais, bem como envolvimentos afetivos e conjugais, com "gringos". Observei nestas mulheres múltiplas intencionalidades e motivações em relação a tais relacionamentos. As expectativas de ganhos econômicos e ascensão social são relevantes, mas há também forte componente subjetivo nos projetos de jovens prostitutas, que circulam nas noites da P.I., de namorar e casar com estrangeiros.

\section{Considerações finais}

Sem desconsiderar assimetrias de gênero e classe social nas relações entre garotas de programas locais e "gringos", nem as formas de dominação daí decorrentes, ressalto que estas mulheres têm se mostrado habilidosas em transformar "programas" em relações afetivas duradouras. Há uma certa desenvoltura por parte de jovens nativas ao aproveitar oportunidades econômicas, subjetivas e existenciais decorrentes de "encontros" ensejadas pelo "mercado do sexo" de dimensões transnacionais, operante no cotidiano noturno da Praia de Iracema. Namoros, casamentos e relações pautadas na "ajuda" com "gringos" lhes resultam não apenas em dinheiro, presentes, viagens internacionais ou residências em outros países, tais vínculos acabam por interferir nas desigualdades e assimetrias da sociedade local.

De modo intencional ou não, turistas estrangeiros operam um alargamento no espaço social e geográfico por onde se movimentam as frequentadoras das noites e madrugadas da Praia de Iracema. Em dimensões espaciais e simbólicas, estes homens lhes "mostram o mundo", e não só o que está longe de suas casas, mostram-lhes também o que está geograficamente próximo: foi na condição de acompanhantes de estrangeiros em férias que a maior parte das minhas interlocutoras vieram adentrar ambientes luxuosos no Ceará(condomínios, restaurantes, hotéis e resorts), onde jamais tinham ido antes de ingressarem na prostituição. Ao manifestarem incômodo diante de mulheres locais acompanhadas de "gringos" em diferentes ambientes da cidade, uma parte dos meus entrevistados de classe média e alta de Fortaleza parece ávida por limitar e circunscrever o 
espaço de trânsito destas jovens, que, em seu entendimento, estariam mais seguras ou protegidas nos seus bairros de origem ou ocupando postos mal remunerados em serviços domésticos ou atividades subordinadas nas indústrias e estabelecimentos comerciais locais. $\mathrm{Na}$ contramão deste anseio, os turistas estrangeiros as permitem "ocupar" espaços elitizados da cidade onde moram e "circular" pelo mundo. Os "gringos" alargam geográfica e simbolicamente os horizontes destas moças, acompanhando-as em incursões aos "bairros nobres" de Fortaleza e inserindo outros países em suas rotas de circulação, seja por meio de passeios ao exterior ou de casamentos e migrações internacionais.

Em decorrência de envolvimentos sexuais e afetivos com homens estrangeiros, estas jovens conseguem experimentar rotinas e momentos com os quais sonharam na infância e adolescência: embarcam em voos internacionais, visitam e fotografam(e postam nos seus perfis nas redes sociais) cidades, atrações e monumentos mundialmente conhecidos, como a torre Eiffel em Paris, o Coliseu em Roma, o Parque Güell em Barcelona, dentre outros ícones do turismo internacional recorrentes em suas fotografias. Embora a maioria das mulheres que conheci durante o trabalho de campo não tenha chegado a residir no exterior, todas têm casos de irmãs, primas ou amigas casadas com "gringos", que aparecem em suas falas como uma referência ou exemplo a ser seguido.

Os homens estrangeiros, além de mobilizados por jovens da periferia de Fortaleza como um tipo de cicerone em trajetos por sua própria cidade e pelo mundo, também funcionam como "amortecimento social" ao preconceito e hostilidade de elites locais. Em alguns casos, a relação com estes homens na condição de namorado ou marido chega a operar reconfigurações de posições em relações hierárquicas. A proximidade, convívio, os vínculos conjugais com "gringos" e as experiências vinculadas ao cenário internacional, são acionadas por garotas de programas que circulam nas noites da P.I. como um tipo de mediação ou escudo de amortecimento diante da animosidade e desconfiança que costumam lhes direcionar pessoas de classe média e alta em Fortaleza.

\footnotetext{
${ }^{1}$ Doutora em Antropologia Social pela USP, professora do Programa de Pós-Graduação em Sociologia da Universidade Federal do Ceará.

2 A noção de "mercado do sexo" trabalhada neste texto, tal como nos trabalhos de Augustin (2007) e Piscitelli (2011), remete a uma noção ampla de economia, abrangendo intercâmbios materiais e simbólicos pulverizados na relações sociais.
} 
3 Os Institutos Nacionais de Ciência e Tecnologia-INCTs foram implementados pelo CNPq no intuito de fortalecer redes de pesquisadores, conectando núcleos, laboratórios e grupos de pesquisa em diferentes regiões do país.

${ }^{4}$ Embora haja mulheres e travestis que se prostituem em avenidas da Praia de Iracema, privilegiei as que atuam nos bares boates do bairro. Embora ocorra em "pontos" localizados no circuito turísticos da cidade, a maior parte dos clientes da prostituição de rua da P.I. são homens que residem em Fortaleza.

5 Ver notícia veiculada no dia $19 / 12 / 2014$ no jornal Tribuna do Ceará:http://tribunadoceara.uol.com.br/noticias/cotidiano-2/numero-de-mulheres-a-mais-que-homens-doceara-lotaria-quatro-vezes-o-estadio-castelao/

\section{Referências bibliográficas}

AQUINO, J.P.D.

2015 “Intersecções e Pontos de Contato entre o legal e o ilegal no cotidiano noturno da Praia de Iracema". In BARreira, Irlys e BARREIRA, César (orgs.), A cidade como campo de pesquisa: redes, conflitos e lugares. Campinas, Editora Pontes.

2010 Príncipes e Castelos de Areia: um estudo da performance nos grandes roubos. São Paulo, Editora 24 horas.

Agustín, L. M.

2007 Sex at the Margins, migration, labour markets and the rescue industry. Nova York, Zed Books.

BACELAR, J. A.

1982 A família da prostituta. São Paulo, Editora Ática.

BEZERRA, R. G.

2009 O Bairro Praia de Iracema entre o adeus e a boemia: usos e abusos num espaço urbano.

Fortaleza, Edições LEO.

BLAHNCHETTE, T. G.

2001 Gringos. Rio de Janeiro, dissertação, MN/UFRJ.

CARdoso de Oliveira, L. R.

1993 “A vocação crítica da Antropologia”. Anuário Antropológico, ed. 93, Rio de Janeiro, Tempo Brasileiro.

CRAPANZANO, V.

1986 Waiting: the whites of South Africa. Nova York, Random House. 


\section{DiÓGENES, G.}

2008 Os sete sentimentos capitais: Exploração sexual comercial de crianças e adolescentes. São Paulo, Annablume.

FONSECA, C.

1996 “A dupla carreira da mulher prostituta”. Revista Estudos Feministas, n. 1: 7-33. GABRIELLI, C.P.

2011 O Paraíso terreal não é cá e lá: turismo sexual em Salvador-ba. Salvador, tese, UFBA.

GEERTZ, C.

1997 “O senso comum com sistema cultural”. In . O saber local: novos ensaios em antropologia interpretativa. Petrópolis, Vozes.

Kempadoo, K. e DoEZema, J. 1998 Global Sex Workers. Rights, Resistance and Redefinition. Nova York, Routledge. MuLLINGS, B.

1999 "Globalization, tourism, and the International Sex Trade”. In KEMPADOO, K. (org.), Sun, Sex and Gold, Tourism and Sex Work in the Caribbean. Maryland, Rowman and Littlefield.

LIM, L. L.

2004 "El sector del sexo: la contribución económica de una industria". In OsBORne, R. (org.), Trabajadoras del sexo: derechos, migraciones y tráfico en el siglo XXI. Barcelona, Ediciones Bellaterra, pp.57-85.

Piscitelli, A.

2014 "Violência e Afetos: Intercâmbios Sexuais e econômicos na (recente) produção antropológica realizada no Brasil”. Cadernos Pagu, n. 42

2011 "Intercâmbios sexuais, econômicos e afetivos transnacionais: brasileiras nos mercados globais do sexo". IV Congreso de la Red Internacional de Migracióne Desarrollo. Quito, Equador. Disponível em: http://www.flacsoandes.edu.ec/web/imagesFTP/1308602693.Ponencia_Adriana_ Piscitelli.pdf

2007 "Prostituição é estratégia migratória". Entrevista concedida ao jornal Diário do Nordeste, edição 21 de janeiro.

2004 "On gringos and natives: gender and sexuality in the context of international sex tourism in Fortaleza, Brazil”. Vibrant, vol.1. 
JANIA PERLA DIÓGENES DE AQUINO. TURISTAS ESTRANGEIROS E MULHERES LOCAIS...

Porto Neto, H. F. M.

2012 “O Patrimônio Histórico Cultural e a Criminalidade na Praia de Iracema: o impacto das intervenções e ocupações do Espaço Público no Cotidiano e no Sentimento do Bairro". Revista do Ministério Publico do Ceará, ed. 1, vol. 1.

ROCHA Lima, E.

2007 O movimento do espaço: uma experiência urbana na Praia de Iracema. Rio de Janeiro, dissertação, Universidade Federal do Rio de Janeiro.

RosA, R, M.

1999 Vivendo um conto de fadas: ensaio sobre cor e fantasia entre cariocas e estrangeiros. Rio de Janeiro, dissertação, UFRJ.

SAHLINS, M.

2001 Como pensam os "nativos”. São Paulo, Edusp.

Silva, A. P. e BlanCHETTE, T.

2005 “'Nossa Senhora da Help’: sexo, turismo e deslocamento transnacional em Copacabana". Cadernos Pagu, n 25.

TRUONG, T.

1990 Sex, Money and Morality. Londres, Zed Books. 


\title{
Foreign tourists and local women: Sex trade and romance in the nights of Iracema Beach in Fortaleza
}

\begin{abstract}
The article discusses the relations between foreign tourists and native women at Iracema Beach in Fortaleza. The views of residents of the seafront and nearby neighborhoods, whose perception of the "encounters" between "gringos" and local young women are strictly negative, are presented. On the one hand, the women are considered "victims" of the sexual interests of foreigners; on the other hand, they are taken as "guilty" for Fortaleza having become internationally known as a prostitution ring. The text also examines the narratives and perceptions of call girls acting in the nights of Iracema Beach, who emphasize positive experiences afforded by the "gringos", such as drinking and dining in upscale restaurants, gifts, trips abroad and even dating and marrying. Besides highlighting the uncertainty between trade and affection in the sexual and affective exchanges between call girls and "gringos", the article argues that such relations interfere in the local asymmetries and social inequalities.
\end{abstract}

KEYWORDS: Gringos and native women, prostitution, sex tourism in Fortaleza, Iracema Beach, transnational sex trade.

Recebido em dezembro de 2013. Aceito em setembro de 2015. 